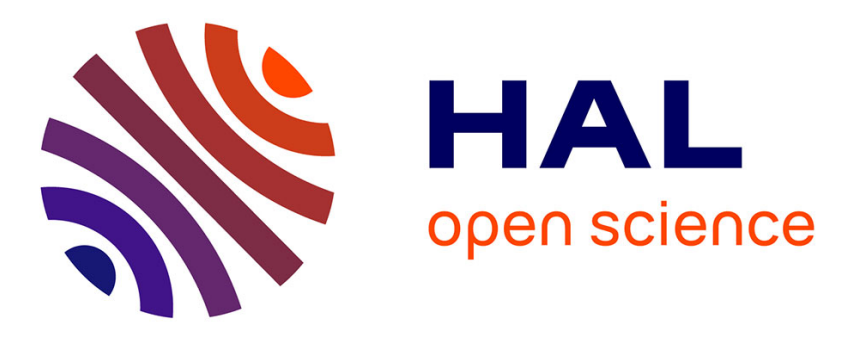

\title{
Triazonine-based bistable photoswitches: synthesis, characterization and photochromic properties
}

Nawel Goual, Lorenzo Casimiro, Vincent Delattre, Pascal Retailleau, Stéphane Maisonneuve, Nicolas Bogliotti, Rémi Métivier, Juan Xie, Angela Marinetti, Arnaud Voituriez

\section{To cite this version:}

Nawel Goual, Lorenzo Casimiro, Vincent Delattre, Pascal Retailleau, Stéphane Maisonneuve, et al.. Triazonine-based bistable photoswitches: synthesis, characterization and photochromic properties. Chemical Communications, 2021, 57 (78), pp.10079-10082. 10.1039/D1CC02746H . hal-03372792

\section{HAL Id: hal-03372792 \\ https://hal.science/hal-03372792}

Submitted on 11 Oct 2021

HAL is a multi-disciplinary open access archive for the deposit and dissemination of scientific research documents, whether they are published or not. The documents may come from teaching and research institutions in France or abroad, or from public or private research centers.
L'archive ouverte pluridisciplinaire HAL, est destinée au dépôt et à la diffusion de documents scientifiques de niveau recherche, publiés ou non, émanant des établissements d'enseignement et de recherche français ou étrangers, des laboratoires publics ou privés. 


\title{
Triazonine-Based Bistable Photoswitches: Synthesis, Characterization and Photochromic Properties
}

\author{
Nawel Goual, ${ }^{a \ddagger}$ Lorenzo Casimiro, ${ }^{b \neq}$ Vincent Delattre, ${ }^{a}$ Pascal Retailleau, ${ }^{\text {a }}$ Stéphane Maisonneuve, ${ }^{b}$ \\ Nicolas Bogliotti, ${ }^{\mathrm{b}}$ Rémi Métivier, ${ }^{\mathrm{b}}$ Juan Xie, ${ }^{* \mathrm{~b}}$ Angela Marinetti*a and Arnaud Voituriez ${ }^{* a}$ \\ a. Université Paris-Saclay, CNRS, Institut de Chimie des Substances Naturelles, UPR 2301, 91198, Gif-sur- \\ Yvette, France. E-mails: arnaud.voituriez@cnrs.fr and angela.marinetti@cnrs.fr \\ b. Université Paris-Saclay, ENS Paris-Saclay, CNRS, PPSM, 91190, Gif-sur-Yvette, France. E-mail: \\ joanne.xie@ens-paris-saclay.fr \\ ¥These authors contributed equally.
}

We disclose here dibenzotriazonines as a new class of ninemembered cyclic azobenzenes displaying a nitrogen function in the saturated ring chain. The specific features of these compounds are (i) a preferred E-configuration, (ii) high bi-directional photoswitching and (iii) good thermal stability of both E- and Zforms.

Among photoswitchable molecular systems, azobenzenes $\mathbf{A}$ (Scheme 1a) occupy a prominent place, ${ }^{1}$ noteworthy applications being referenced in a variety of fields such as material sciences, ${ }^{2}$ photopharmacology ${ }^{3}$ and catalysis. ${ }^{4}$ Meanwhile, simple acyclic azobenzenes have demonstrated also some limitations. Indeed, their $E \rightarrow Z$ photoisomerization reactions are mostly incomplete (e.g. $E / Z$ ratio $\approx 30 / 70$ for the parent azobenzene), and the $Z$-isomers generally display short life-times. Therefore, a number of structural modifications have been implemented to improve their photophysical properties, with special focus on structural changes that might induce bistability. A well-established strategy involves substitution of the benzene rings with electron withdrawing ortho-fluorine substituents, ${ }^{5}$ that led to applications of bistable derivatives as DNA intercalators ${ }^{6 a}$ or in catalysis. ${ }^{6 b}$ Another way to increase the stability of the Z-isomer is to embed azobenzenes into strained cyclic moieties, ${ }^{7}$ such as diazocines ${ }^{8}$ and heterodiazocines B (Scheme 1b). ${ }^{9-11}$ Overall, despite these recent advances, access to bistable azobenzenes which would only convert with light and not thermally, remains a valuable goal. In this context, this study unveils a new family of cyclic, C2 symmetric photoswitchable azobenzenes, the dihydro- $11 \mathrm{H}$ dibenzo[ $[c, h][1,2,6]$ triazonines $\mathbf{C}$ in Scheme 1c. Their properties, namely $E$-preference combined with bistability over a large temperature range, nicely complement the properties of the known azobenzenes and diazocines. It must be emphasized here that only two preliminary studies have been reported so far on nine-membered cyclic azobenzenes.

In 2018, thiadiazonine $E-D(X=S$, Scheme $1 d$ ) has been isolated. Under irradiation at $466 \mathrm{~nm}$, it reached an $Z / E$ ratio $=70 / 30$ at the photostationary state (PSS), with a $t_{1 / 2}=30 \mathrm{~min}$ for the $Z$ isomer at $25^{\circ} \mathrm{C} .{ }^{12 a, b}$ On the other hand, the parent diazonine $\mathbf{D}$ $\left(\mathrm{X}=\mathrm{CH}_{2}\right)$ was isolated as the $Z$-isomer, and reached an $E / Z$ ratio $=86 / 14$ at the $\mathrm{PSS}_{390 .}{ }^{12 \mathrm{c}}$

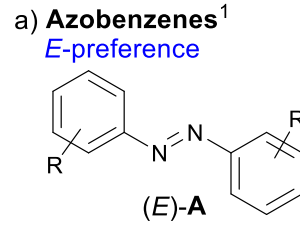

c) Triazonines: This work E-preference, bistability

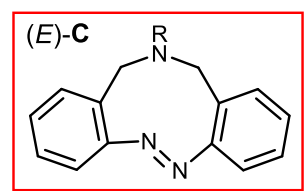
Z-preference

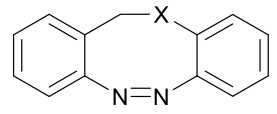

(Z)-B, $\mathrm{X}=\mathrm{CH}_{2}, \mathrm{O}, \mathrm{S}, \mathrm{NR}$

d) Thiadiazonines ${ }^{12 a, b}$ and diazonines ${ }^{12 c}$

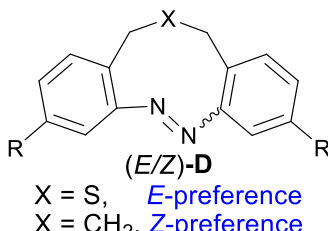

b) Diazocines ${ }^{8}$ and heterodiazocines ${ }^{9}$

Scheme 1. Photoswitchable azobenzenes A, diazocines B, diazonines D and the new dibenzo[1,2,6]triazonine backbone $\mathbf{C}$.

Thus, the nature of the three-atom bridge seems to modulate significantly the properties of these cyclic azobenzenes. By targeting triazonines C, i.e. by introducing a $\mathrm{N}$-atom in the bridge, we were expecting to modulate again the relative photochemical and thermal stability of the two isomers, although the actual effects were hardly predictable.

For the synthesis of the targeted dibenzotriazonines, we have applied either the intramolecular reductive cyclization ${ }^{10 a-d}$ of $2,2^{\prime}$-dinitrodibenzyl carbamates 1 or the oxidative cyclization ${ }^{10 e}$, ${ }^{12 c}$ of the analogous dianilines $\mathbf{3}$ (Scheme 2 ). At first, carbamates 1a-c (Scheme 2a) were prepared from bis(2-nitrobenzyl)amine. From $1 \mathrm{a}(\mathrm{R}=t \mathrm{Bu})$, the reductive cyclization was carried out then with zinc dust and barium hydroxide at $70^{\circ} \mathrm{C}$ in an ethanol/water mixture. Unlike other procedures, ${ }^{9 a, 10 a-b}$ this method does not make use of toxic lead or mercury reagents. The oxidation of the hydrazine intermediate has been achieved by adding $\mathrm{CuCl}_{2}$ (4 mol\%) and sodium hydroxide. From these experiments, compound $2 \mathrm{a}(\mathrm{R}=t \mathrm{Bu})$ was isolated as the single $E$-isomer in $36 \%$ yield at a gram scale. The same reaction conditions were applied to substrates $\mathbf{1 b}$ and $\mathbf{1 c}$ : triazonines $\mathbf{2 b}$ $(R=B n)$ and $2 c(R=E t)$ were obtained in $34 \%$ and $52 \%$ yield. Triazonine $\mathbf{2 b}$ was obtained as the pure $E$-isomer, while triazonine $2 c$ was isolated as an $E / Z=80 / 20$ isomeric mixture. 


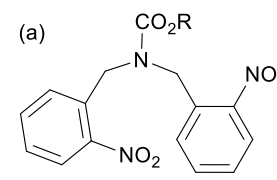

1a-c
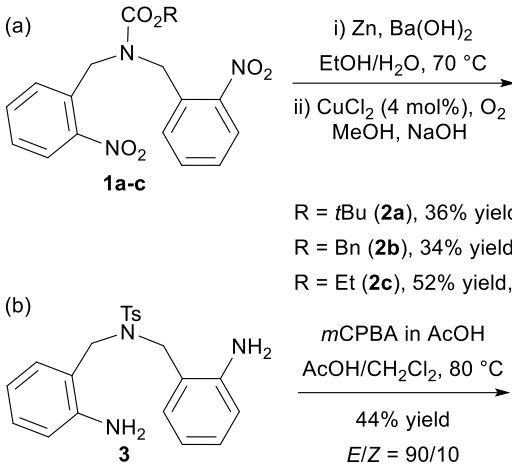

2a-c
$\mathrm{R}=t \mathrm{Bu}(\mathbf{2 a}), 36 \%$ yield (gram scale), $E / Z>99 / 1$

$\mathrm{R}=\mathrm{Bn}(\mathbf{2 b}), 34 \%$ yield, $E / Z>99 / 1$

$\mathrm{R}=\mathrm{Et}(\mathbf{2 c}), 52 \%$ yield, $E / Z=80 / 20$
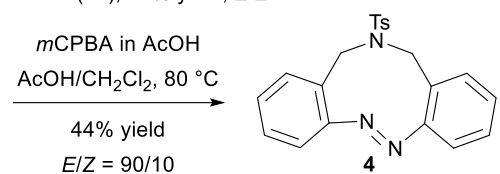

Scheme 2. Synthesis of $N$-protected dibenzotriazonines via (a) reductive and (b) oxidative cyclizations.

In further experiments, compound $\mathbf{3}$ was converted into triazonine 4 under oxidative conditions, in $m C P B A / A c O H$ at 80 ${ }^{\circ} \mathrm{C}$ (44\% yield, 90/10: $E / Z$ mixture, Scheme $2 b$ ). Alternatively, starting from $\mathrm{N}, \mathrm{N}$-bis(2-nitrobenzyl)tosylamine and using reductive conditions, triazonine 4 was isolated in a lower $31 \%$ yield (see ESI). Interestingly, this last procedure led to $\mathbf{4}$ in a $80 / 20 \mathrm{E} / \mathrm{Z}$ ratio. Thus, the divergent stereochemical outcome of the two procedures suggests a kinetic control of the isomer ratio in these reactions.

The new triazonines $\mathbf{2 a - c}$ and $\mathbf{4}$ have been fully characterized by NMR, UV-vis spectroscopy and X-ray crystallography. The UVvis spectra are reported in Figure 1 and Figure S2. In the case of 4, for which only an $E / Z$ mixture was available, the spectra were deconvoluted from those of the mixtures (Fig. S3). The four $E-$ triazonines display the spectral features of $E$-azobenzene derivatives. ${ }^{1,9 b}$ The weak $n-\pi^{*}$ bands in the visible region span from $420 \mathrm{~nm}$ (for $2 \mathrm{c}$ ) to $426 \mathrm{~nm}$ (for 2a), and their absorption coefficients $(\varepsilon)$ are comprised between $190 \mathrm{M}^{-1} \mathrm{~cm}^{-1}$ (for $\mathbf{2 b}$ and 4) and $260 \mathrm{M}^{-1} \mathrm{~cm}^{-1}$ (for $2 \mathrm{a}$ ). The strong $\pi-\pi^{*}$ bands in the UV range are centred at $303 \mathrm{~nm}$ for $\mathbf{2 a}, 307 \mathrm{~nm}$ for $\mathbf{2 b}, 304 \mathrm{~nm}$ for 2c and $308 \mathrm{~nm}$ for $\mathbf{4}$, with absorption coefficients comprised between $6800 \mathrm{M}^{-1} \mathrm{~cm}^{-1}$ (for $\mathbf{2 b}$ ) and $8390 \mathrm{M}^{-1} \mathrm{~cm}^{-1}$ (for 2a). The positions and the coefficients of the absorption bands are consistent with those of previously reported cyclic azobenzenes. ${ }^{8 d, 9,12 a}$ The third absorption band at around $230 \mathrm{~nm}$ is the only one that differs in shape (non-symmetrical shapes for $2 \mathrm{a}-\mathrm{c}$ ) and intensity between the four compounds. This suggests that the amine protecting groups influence only marginally the absorption features, their contribution being limited at the far UV edge, where the Boc, $\mathrm{Cbz}$ and Tosyl groups themselves absorb.

The photoisomerization of compounds E-2a-c and $\mathbf{4}$ was investigated then by UV-vis spectroscopy in acetonitrile solutions. As a representative example, the behaviour of triazonine $\mathbf{2 a}$ is discussed hereafter (Figure 2). UV or visible light irradiation of $E$-2a produces the typical absorbance variations related to $E-Z$ photoswitching: ${ }^{1}$ the $\pi-\pi^{*}$ band decreases in intensity, while the $n-\pi^{*}$ increases and shifts towards higher energies (Figure 2a). These trends are validated by the UV-vis absorption spectra of the isolated $Z-2 a$ in which the $\pi-\pi^{*}$ band

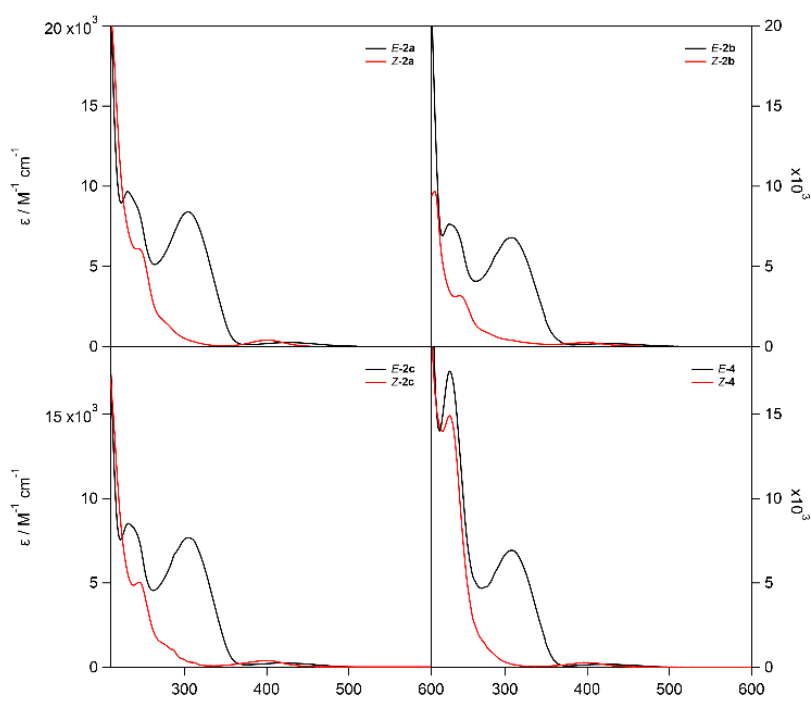

Figure 1. Absorption spectra in $\mathrm{CH}_{3} \mathrm{CN}$ of $E$ - (black) and Z-isomers (red) of 2a (top left), $\mathbf{2 b}$ (top right), 2c (bottom left) and $\mathbf{4}$ (bottom right).

appears as a shoulder at around $300 \mathrm{~nm}$, while the $n-\pi^{*}$ band is blueshifted of $25 \mathrm{~nm}$ and has a larger absorption coefficient with respect to the $E$-form ( 410 vs $260 \mathrm{M}^{-1} \mathrm{~cm}^{-1}$ ). Interestingly, this blueshift results in a good resolution of the $n-\pi^{*}$ bands between the $E$ and $Z$ isomers as it usually happens in diazocines and ortho-fluorinated azobenzenes.5,9,11a Throughout the $E \rightarrow Z$ photoisomerization process, the isosbestic points at $224 \mathrm{~nm}$, $368 \mathrm{~nm}$ and $420 \mathrm{~nm}$ were maintained and the related Mauser plot $^{13}$ (Figure S4) confirmed that only the $E / Z$ photoisomerization took place.

As expected, the PSSs (Figure $2 \mathrm{~b}$, Table 1 ) were richer in the $Z$ isomer upon irradiation in the UV, while the $E$-isomer predominates under irradiation in the violet edge of the visible spectrum. The photoconversion yield $\alpha_{z}$, i.e., the fraction of the $Z$ isomer, at the photostationary state is $0.93,0.90$ and 0.14 at respectively $334 \mathrm{~nm}, 313 \mathrm{~nm}$, and $405 \mathrm{~nm}$. Interestingly, due to the good resolution between the $n-\pi^{*}$ bands of the $E$ and $Z$ isomers, the isomerization can be pushed toward the $Z$ isomer also by irradiation in the blue region of the visible spectrum, with $\alpha_{Z}=0.45$ at $436 \mathrm{~nm}$ (Table S2). The $E \rightarrow Z$ quantum yields $\left(\Phi_{E Z}\right)$ range between 0.08 and 0.15 , whereas $\Phi_{Z E}$ are comprised between 0.33 and 0.50 . These quantum yield values are closer to those of acyclic azobenzenes rather than diazocines. ${ }^{1,8,14}$ The dibenzotriazonines $\mathbf{2 b}, \mathbf{2 c}$ and $\mathbf{4}$ display analogous photochemical behaviours, with high conversion yields for the $E \rightarrow Z$ isomerization under UV irradiation: $\alpha_{Z}=0.96$ for $\mathbf{2 b}, 0.97$ for $\mathbf{2 c}$ and 0.98 for 4 (at $334 \mathrm{~nm}$, Table 1). The photoswitching between $E$ - and Z-enriched PSSs is reversible, with moderate fatigue resistance for $\mathbf{2 a}$ and good fatigue resistance for $\mathbf{2} \mathbf{b}$ and 4 , at up to 10 consecutive alternate irradiations at 334 and 405 $\mathrm{nm}$ wavelengths (Figure S7-9). Thus, the experiments above demonstrate that the photophysical behaviour of the newly disclosed dibenzotriazonines nicely complements those of both acyclic azobenzenes and diazocines. The thermal isomerization of $2 \mathrm{a}$ was investigated by ${ }^{1} \mathrm{H}$ NMR experiments (Figures S11-16). At $25{ }^{\circ} \mathrm{C}$, the ${ }^{1} \mathrm{H}$ NMR spectrum of $Z$-2a in $\mathrm{CDCl}_{3}$ remained mainly unchanged after 45 days, showing that both $Z$ and $E$ forms 

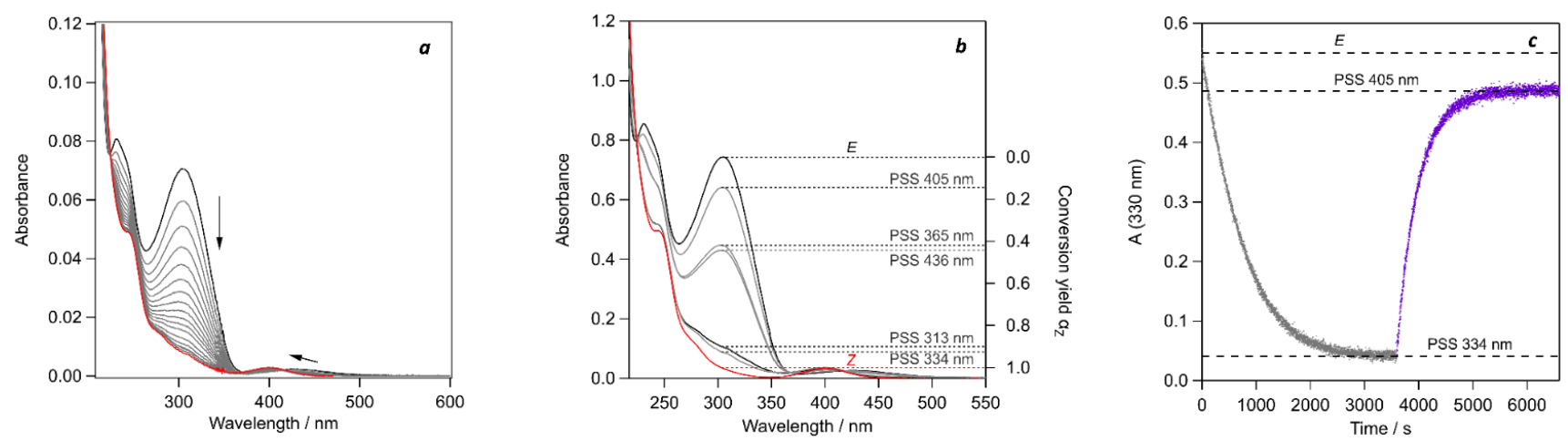

Figure 2. (a) Absorption evolution of a $8.4 \times 10^{-6} \mathrm{M} \mathrm{CH}_{3} \mathrm{CN}$ solution of $E$-2a under irradiation at $334 \mathrm{~nm}$; (b) Absorbance of $E$ - and $Z$-2a (red), absorbance and conversion yields at the PSSs (grey); (c) Photokinetic profiles under irradiation at $334 \mathrm{~nm}$ (grey dots) and $405 \mathrm{~nm}$ (purple dots) of a $7 \times 10^{-5} \mathrm{M}$ solution of $2 \mathrm{a}$ (1.5 mW at $334 \mathrm{~nm}$ and $5.3 \mathrm{~mW}$ at $405 \mathrm{~nm}$ ).

Table 1. $E \rightarrow Z$ Photoconversion yields $\left(\alpha_{z}\right)$ and quantum yields $(\Phi)$ for $\mathbf{2 a - c}$ and 4 in $\mathrm{CH}_{3} \mathrm{CN}$, at 334 and $405 \mathrm{~nm}$.

\begin{tabular}{ccccc}
\hline Compound & $\lambda_{\text {irr }} / \mathrm{nm}$ & $\alpha_{Z}$ & $\Phi_{E Z}$ & $\Phi_{Z E}$ \\
\hline 2a & 334 & $0.93(93 \% Z)$ & 0.13 & 0.50 \\
& 405 & $0.14(86 \% E)$ & 0.08 & 0.33 \\
\hline 2b & 334 & $0.96(96 \% Z)$ & 0.12 & 0.30 \\
& 405 & $0.10(90 \% E)$ & 0.14 & 0.56 \\
\hline 2c & 334 & $0.97(97 \% Z)$ & 0.20 & 0.23 \\
& 405 & $0.18(82 \% E)$ & 0.14 & 0.39 \\
\hline $\mathbf{4}$ & 334 & $0.98(98 \% Z)$ & 0.17 & 0.20 \\
& 405 & $0.30(70 \% E)$ & 0.21 & 0.35 \\
\hline
\end{tabular}

display a good stability in solution. From the kinetic study, halflife of $Z$-2a was estimated to be $t_{1 / 2} \approx 6300$ days (about 17 years) at $25{ }^{\circ} \mathrm{C}$. Then, a $\mathrm{CDCl}_{3}$ solution of either $E$ - or $Z-2 \mathrm{a}$ has been charged in an NMR tube and heated in an oil bath at $80^{\circ} \mathrm{C}$. NMR spectra have been recorded at different reaction times. Considering that the boiling point of $\mathrm{CDCl}_{3}$ is $60.9{ }^{\circ} \mathrm{C}$, the effective temperature of the solution should be close to this value. Heating a sample of $Z$-2a causes a slow isomerization into the $E$-isomer $\left[t_{1 / 2}=19.5\right.$ days]. This behaviour contrasts with that of the dibenzo-thiadiazonines $\mathbf{D}(X=S$, Scheme $1 \mathrm{~d})$ for which conversion of the $E$-isomer into the thermodynamically favoured Z-isomer was completed in less than 30 minutes at room temperature (see SI for more comparative details between cyclic azobenzenes).12a The remarkable thermal stability of triazonines enabled X-ray analysis of both $E$ - and $Z$ isomers to be carried out. ORTEP drawings for $E$ - and $Z-2 a$ are displayed in Figure 3 . In the $E$-isomer, the large deviation of the
$E-2 a$

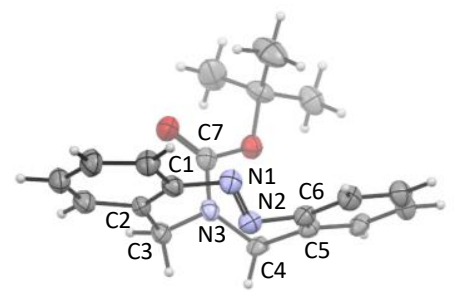

$Z-2 a$

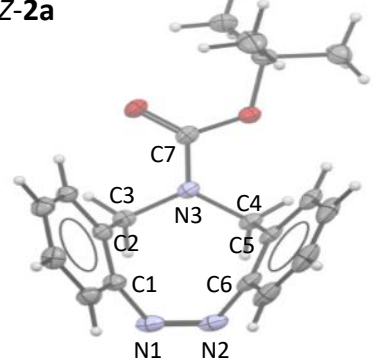

Figure 3. Ortep drawing for compounds $E-2 a$ and $Z-2 a$. Selected bond lengths $(\AA ̊)$ and angles (deg) for $E-2 \mathrm{a} / Z-2 \mathrm{a}$ : N1-N2 = 1.251(3)/1.246(2); N1-C1 = $1.421(3) / 1.455(2) ; \mathrm{C} 1-\mathrm{C} 2=1.403(3) / 1.396(2) ; \mathrm{C} 3-\mathrm{N} 3=1.466(3) / 1.462(2)$; N2$\mathrm{N} 1-\mathrm{C} 1=111.6(3) / 120.0(1) ; \mathrm{N} 1-\mathrm{C} 1-\mathrm{C} 2=119.9(3) / 119.7(1) ; \mathrm{C} 1-\mathrm{C} 2-\mathrm{C} 3=$ 126.1(3)/121.7(1); C2-C3-N3 = 119.0(3)/114.5(1).
C1-N1-N2-C6 dihedral angle $\left(163.0^{\circ}\right)$ from the expected $180^{\circ}$, as well as the N2-N1-C1 bond angle of $111.6^{\circ}$, demonstrate the significant conformational distortion of the molecule due to its 9-membered cyclic structure. A similar distortion was observed previously in the $E$-thiadiazonine derivative D. ${ }^{12 a} \operatorname{In} Z$-2a, the C1N1-N2-C6 dihedral angle of $0.4^{\circ}$ indicates a planar diazo moiety. $\mathrm{X}$-ray data do not highlight especially unusual bond distances (e.g. the $\mathrm{N}=\mathrm{N}$ bond distances measure 1.246(2) $\AA$ and 1.251(3) $\AA$ in $E$ - and $Z$-2a respectively), which suggests moderate ring strain for both the $E$ - and $Z$-forms, in overall agreement with the observed bistability of these triazonines. Moreover, the X-ray crystal structures of $E / Z-2 c$ and $E-4$ reported in the ESI demonstrate that the triazonine core is almost identical in the whole series, irrespective of the $N$-protection group. As a suitable metric to compare the 3D arrangement of the $E$ vs $Z$ forms, we can take the non-bonding distances between the two $\underline{\mathrm{CH}}$ atoms in ortho-positions to the azo functions. These distances measure $5.23 \AA$ and $3.80 \AA$ in $E-2 \mathbf{a}$ and $Z-2 \mathrm{a}$ respectively. Although the difference between the $E$ - and $Z$ forms is smaller than in acyclic azobenzenes, ${ }^{6 c}$ the structural differences observed in the solid state should be retained in solution, since triazonines are largely conformationally locked by their cyclic structures. Such a difference prefigures major changes of their physicochemical properties, under the effect of light, as specifically sought in photoswitchable systems.

Finally, as a complement to spectroscopic and structural characterizations, we have investigated the geometries, energy levels and molecular orbitals of the ground states of $E$ - and Z-2a by DFT (B3LYP functional, 6-311+G** basis set). We have also simulated their absorption spectra by TD-DFT calculations with either the B3LYP or CAM-B3LYP functionals. ${ }^{15}$ The solvent $\left(\mathrm{CH}_{3} \mathrm{CN}\right)$ was implemented with the CPCM model of Gaussian. The optimized geometries of $E$ - and Z-2a are fully consistent with the $X$-ray structures. In the ground state, $Z$-2a turns out to be less stable than $E-2 \mathrm{a}$ by $3.34 \mathrm{kcal} \mathrm{mol}^{-1}$, meaning that the $E: Z$ population would be 99.6:0.4, if the thermal interconversion was allowed at r.t. (Table S10). The electronic transitions calculated with the CAM-B3LYP functional resulted to be fully consistent with the experimental absorption spectra (Figure 4 and ESI). According to NTO analyses, the computed transitions at 442 and $414 \mathrm{~nm}$ for the $E$ - and $Z$-isomers respectively, display a $n-\pi^{*}$ character, while the transitions in the UV region, at 301 and $275 \mathrm{~nm}$ for the $E$ and $Z$ isomers, possess a $\pi-\pi^{*}$ character. 


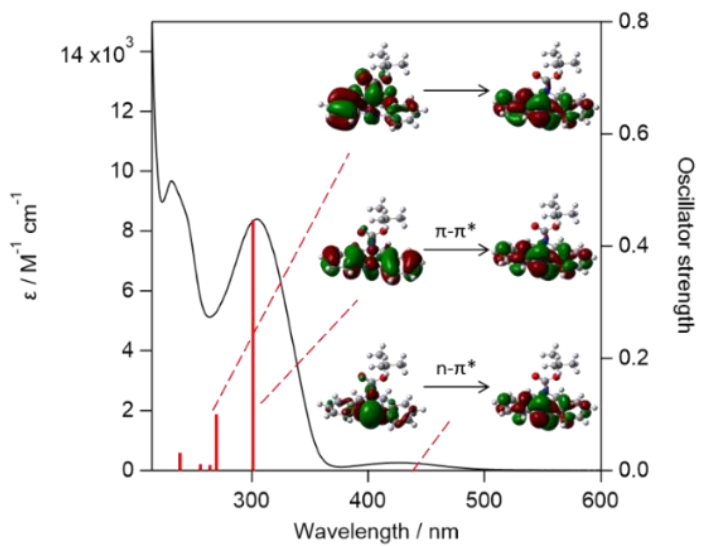

Figure 4. NTO orbitals, calculated transitions and experimental spectra of $E$ 2a in $\mathrm{CH}_{3} \mathrm{CN}$.

The calculated energies as well as the magnitude of the oscillator strengths reflect well the experimental data. The nature of the orbitals contributing to the higher energy bands could not be univocally assigned, however calculations showed that, in the $E$-isomers, the carbonyl moieties or the tosyl group on nitrogen become involved in the transition (Figures S26-27). These results confirm that the protecting group may influence the absorption spectrum in the far UV region.

In summary, four dibenzotriazonines have been prepared as a new series of nine-membered cyclic azobenzenes. The key features of these unprecedented photochromic compounds include: (1) the high conversion yields for both the $E \rightarrow Z$ and the reverse $Z \rightarrow E$ isomerization processes under irradiation; (2) the high thermal stability of both the $E$ - and $Z$-isomers. Further studies will target the synthesis of functionalized analogues for selected applications in photoswitch processes taking advantage from their inherent physicochemical properties.

This work has been supported by the ANR ("Switch-Phos" project, ANR-17-CE07-0032) and the LabEx CHARMMMAT (ANR-11-LABX-0039). HPC resources were provided by the "Mésocentre" computing center of CentraleSupélec and ENS Paris-Saclay, supported by CNRS and Région île-de-France (http://mesocentre.centralesupelec.fr/).

\section{Notes and references}

1 H. M. D. Bandara and S. C. Burdette, Chem. Soc. Rev., 2012, 41, 1809.

2 (a) L. Dong, Y. Feng, L. Wang and W. Feng, Chem. Soc. Rev. 2018, 47, 7339; (b) G. Xu, S. Li, C. Liu and S. Wu, Chem. Asian J., 2020, 15, 547; (c) A. Goulet-Hanssens, F. Eisenreich and S. Hecht, Adv. Mater., 2020, 32, 1905966.

3 (a) A. A. Beharry and G. A. Woolley, Chem. Soc. Rev., 2011, 40 4422; (b) J. Broichhagen, J. A. Frank and D. Trauner, Acc. Chem. Res., 2015, 48, 1947; (c) I. M. Welleman, M. W. H. Hoorens, B. L. Feringa, H. H. Boersma and W. Szymański, Chem. Sci., 2020, 11, 11672.

4 (a) R. Göstl, A. Senf and S. Hecht, Chem. Soc. Rev., 2014, 43, 1982; (b) V. Blanco, D. A. Leigh and V. Marcos, Chem. Soc. Rev., 2015, 44, 5341; (c) R. Dorel and B. L. Feringa, Chem. Commun., 2019, 55, 6477; (d) F. Medici, N. Goual, V. Delattre, A. Voituriez and A. Marinetti, ChemCatChem, 2020, 12, 5573.

5 (a) D. Bléger, J. Schwarz, A. M. Brouwer and S. Hecht, J. Am. Chem. Soc., 2012, 134, 20597; (b) C. Knie, M. Utecht, F. Zhao,
H. Kulla, S. Kovalenko, A. M. Brouwer, P. Saalfrank, S. Hecht and D. Bléger, Chem. Eur. J., 2014, 20, 16492; (c) J. Calbo, A. R. Thawani, R. S. L. Gibson, A. J. P. White and M. J. Fuchter, Beilstein J. Org. Chem., 2019, 15, 2753.

6 (a) B. Heinrich, K. Bouazoune, M. Wojcik, U. Bakowsky and O. Vázquez, Org. Biomol. Chem., 2019, 17, 1827; (b) T. Arif, C. Cazorla, N. Bogliotti, N. Saleh, F. Blanchard, V. Gandon, R. Metivier, J. Xie, A. Voituriez and A. Marinetti, Catal. Sci. Technol., 2018, 8, 710.

7 For representative examples of macrocyclic azobenzenes, see: (a) S. Shinkai, T. Nakaji, Y. Nishida, T. Ogawa and O. Manabe, J. Am. Chem. Soc., 1980, 102, 5860; (b) M. Mathews and N. Tamaoki, J. Am. Chem. Soc., 2008, 130, 11409; (c) G. Haberhauer and C. Kallweit, Angew. Chem. Int. Ed., 2010, 49, 2418; (d) K. Takaishi, M. Kawamoto, A. Muranaka and M. Uchiyama, Org. Lett., 2012, 14, 3252; (e) C. Lin, J. Jinbiao, S. Maisonneuve, J. Mallétroit, J. Xie, Chem. Commun., 2020, 56, 3261; ( $f)$ N. Eleya, S. Ghosh, E. Lork and A. Staubitz, J. Mater. Chem. C, 2021, 9, 82; (g) S. Vela, A. Scheidegger, R. Fabregat and C. Corminboeuf, Chem. Eur. J., 2021, 27, 419.

8 (a) Duval, H. Bull. Soc. Chim. Fr., 1910, 7, 727; (b) W. W. Paudler and A. G. Zeiler, J. Org. Chem., 1969, 34, 3237; (c) E. Tauer and R. Machinek, Liebigs Annalen, 1996, 1213; (d) R. Siewertsen, H. Neumann, B. Buchheim-Stehn, R. Herges, C. Naether, F. Renth and F. Temps, J. Am. Chem. Soc., 2009, 131, 15594; (e) M. Böckmann, N. L. Doltsinis and D. Marx, Angew. Chem. Int. Ed., 2010, 49, 3382; (f) R. Siewertsen, J. B. Schoenborn, B. Hartke, F. Renth and F. Temps, Phys. Chem. Chem. Phys., 2011, 13, 1054.

9 (a) M. Hammerich, C. Schuett, C. Staehler, P. Lentes, F. Roehricht, R. Hoeppner and R. Herges, J. Am. Chem. Soc., 2016, 138, 13111; (b) P. Lentes, E. Stadler, F. Roehricht, A. Brahms, J. Groebner, F. D. Soennichsen, G. Gescheidt and R. Herges, J. Am. Chem. Soc., 2019, 141, 13592; (c) W. Moormann, T. Tellkamp, E. Stadler, F. Röhricht, C. Näther, R. Puttreddy, K. Rissanen, G. Gescheidt, R. Herges, Angew. Chem. Int. Ed., 2020, 59, 15081.

10 (a) D. K. Joshi, M. J. Mitchell, D. Bruce, A. J. Lough and H. Yan, Tetrahedron, 2012, 68, 8670; (b) C. Deo, N. Bogliotti, R. Metivier, P. Retailleau and J. Xie, Chem. Eur. J., 2016, 22, 9092; (c) W. Moormann, D. Langbehn and R. Herges, Synthesis, 2017, 49, 3471; (d) M. Schehr, D. Hugenbusch, T. Moje, C. Naether and R. Herges, Beilstein J. Org. Chem., 2018, 14, 2799; (e) S. Li, N. Eleya and A. Staubitz, Org. Lett., 2020, 22, 1624.

11 For selected applications, see: (a) S. Samanta, C. Qin, A. J. Lough and G. A. Woolley, Angew. Chem. Int. Ed., 2012, 51, 6452; (b) T. Tellkamp, J. Shen, Y. Okamoto and R. Herges, Eur. J. Org. Chem., 2014, 5456; (c) S. Li, G. Han and W. Zhang, Macromolecules, 2018, 51, 4290; (d) E. R. Thapaliya, J. Zhao and G. C. R. Ellis-Davies, ACS Chem. Neurosci., 2019, 10, 2481.

12 (a) M. Saha, S. Ghosh and S. Bandyopadhyay, New J. Chem., 2018, 42, 10784; (b) M. Saha, S. Chatterjee, M. S. Hossain, A. Ghude and S. Bandyopadhyay, Chem. Asian J. 2019, 14, 4659; (c) M. S. Maier, K. Hüll, M. Reynders, B. S. Matsuura, P. Leippe, T. Ko, L. Schäffer and D. Trauner, J. Am. Chem. Soc., 2019, 141, 17295; (d) For triazonine $N$-dioxides, see: M. A. Smith, B. Weinstein and F. D. Greene, J. Org. Chem., 1980, 45, 4597.

13 (a) H. Mauser, Z. Naturfosch, 1968, 23b, 1025; (b) H. Mauser, Formale Kinetik, Bertelsmann Univ., Dusseldorf, 1974.

14 (a) V. Ladányi, P. Dvořák, J. Al Anshori, L'. Vetráková, J. Wirz and D. Heger, Photochem. Photobiol. Sci., 2017, 16, 1757; (b) G. Zimmerman, L.-Y. Chow and U.-J. Paik, J. Am. Chem. Soc., 1958, 80, 3528; (c) Y. Shigeru, O. Hiroshi and T. Osamu, Bull. Chem. Soc. Jpn., 1962, 35, 1849; (d) L. Liu, S. Yuan, W. H. Fang and Y. Zhang, J. Phys. Chem. A, 2011, 115, 10027.

15 D. Jacquemin, J. Preat, E. A. Perpète, D. P. Vercauteren, J.-M. André, I. Ciofini and C. Adamo, Int. J. Quantum Chem., 2011, 111, 4224. 